\title{
The Impact of Financial Sector Development on Foreign Direct Investment: An Empirical Study on Minimum Threshold Levels
}

\author{
Kunofiwa Tsaurai, Daniel Makina \\ University of South Africa, Department of Finance, Risk Management and Banking, South Africa \\ tsaurk@unisa.ac.za, kunofiwa.tsaurai@gmail.com
}

\begin{abstract}
Using panel data of 21 emerging economies, the paper investigates the financial sector development threshold levels that would influence foreign direct investment (FDI) inflows. The threshold levels we identified are $41.27 \%$ of stock market capitalization for stock market turnover, $53.55 \%$ of gross domestic product (GDP) for stock market value traded, 121.53\% of GDP for stock market capitalization, $114.43 \%$ of GDP for domestic credit to private sector by banks, $144.06 \%$ of GDP for domestic credit provided by financial sector, $0.22 \%$ of GDP for outstanding domestic private debt securities and $41.26 \%$ of GDP for outstanding domestic public debt securities. Our results show that higher stock market and banking sector development above the threshold level positively and significantly influence FDI inflows whilst the influence of lower stock market and banking sector development on FDI inflows was weak and not significant. Levels of private bond market development equal to or greater than the threshold level are found to have a positive but non-significant impact on FDI inflows whilst private bond market development levels less than the threshold have a weaker positive and non-significant influence on FDI inflows. On the other hand, public bond market development levels equal to or greater than the threshold level negatively influenced FDI inflows whilst levels of public bond market development less than the threshold positively but non-significantly attracted FDI inflows into emerging markets.
\end{abstract}

Keywords: Foreign Direct Investment; Financial Sector Development; Endogeneity; Threshold; Emerging Markets

\section{Introduction}

Empirical literature recently observed that FDI influences economic growth on condition that absorption capacities are not just present in the host country but have reached a minimum level needed to make use of the technology, knowledge and other skills associated with FDI (Vita and Kyaw. 2009). According to Asong (2014), financial sector development is among the absorption capacities that must be present in the host country to ensure significant FDI inflows. Focusing on Sub-Saharan African countries, Sghaier and Abida (2013) suggested that these countries could only benefit from technological diffusion that comes with FDI if their financial systems reach a certain minimum level of development. Choong (2012:828) acknowledged that financial sector development must reach a certain minimum threshold point before FDI inflows positively and significantly influence economic growth in the host countries. In a panel study of BRICS (Brazil, Russia, India, China and South Africa) countries, Kaur et al. (2013) reported that developed financial markets enable host countries to benefit from FDI through better provision of financial support in terms of quicker transactions, provision of loans, good foreign currency services and optimal allocation of capital to more deserving projects.

Furthermore, Balasubramanyam et al (1996:96) showed that well developed financial markets guarantee that the environment in which FDI operates is competitive, free from market distortions and promotes knowledge transfer among firms. Supporting this view are Huang and Xu (1999) who argue that financial institutions influence the FDI by increasing the speed of technological innovation that arises from different channels of FDI technology spill-overs. In our study we hypothesize that there is a certain threshold level of financial sector development that influences significant inflows of FDI. Given that UNCTAD (2012) reported that FDI flow over the years has proven to be a major source of economic growth and development especially for emerging markets, the research problem of our study centres on the empirical question: What minimum threshold levels must financial sector development reach to trigger FDI inflows in emerging markets? This empirical question is far from being conclusively addressed in emerging markets and other countries in the world. 
In the literature this question has been investigated in an inconclusive manner (see for instance, Dutta and Roy, 2011 who focused on countries from Central Asia, Europe, South Asia, East Asia and Pacific, Middle East, North Africa, Sub-Saharan Africa, Latin America and the Caribbean; Azman-Saini et al. 2010 who focused on countries drawn from different economic sub-groups and income levels; Omran and Bolbol, 2003 who focused on Arabic countries; and Hermes and Lensink, 2003 who focused on less developing countries). We observe that these prior studies have a number of methodological weaknesses. Cross-country threshold regression models they employ use ordinary least squares (OLS) that do not address the endogeneity problem (FDI being endogenous to itself via the lagged value). They also used the standard within transformation approach by Hansen (1999) to eliminate the individual country-specific fixed effects which are incapable of effectively dealing with a serial correlation of transformed error terms. In these prior studies, the fact that current FDI is affected by the previous FDI (dynamic nature of FDI) was completely ignored, and the FDI proxy used was not one that indicated foreign investors' change in position in the host country.

Only banking sector development proxies are used whilst stock and bond market proxies are neglected, which is a narrow representation of the financial markets. Moreover, no study has been done on emerging markets as a bloc with regards to the subject matter. Our study attempts to address these shortcomings by using a modified Kremer et al. (2013)'s dynamic panel threshold regression model. In summary, the major objective of this paper is to investigate the minimum threshold levels that financial development must reach in emerging markets in order for significant FDI inflow to take place. The study is expected to help emerging markets to develop sound financial development policies that enhance the inflow of significant FDI into their economies. The rest of the paper is structured as follows: Section 2 reviews the relevant literature. Section 3 describes the methodology employed in the study. Section 4 presents and discusses the results of the study. Section 5 concludes.

\section{Review of Relevant Literature}

Consistent with Ezeoha and Cattaneo (2012), the impact of financial sector development on FDI is summarised into the allocative channel, economic efficiency and the liquidity easing theoretical rationales. Proponents of the allocative channel rationale including Kaur et al. (2013), among others, argue that well developed financial markets are better able to increase foreign capital productivity through allocating financial resources to projects with a high rate of return. The economic efficiency rationale proposes that well developed financial markets have got the better capacity to ease information flow and reducing transaction costs thereby positively influencing FDI (Claessen and Laeven, 2003; Bartels et al., 2009; Ezeoha and Cattaneo, 2012). The liquidity easing rationale argues that well developed financial markets boost liquidity, allow faster trading of financial instruments and settlement by multinational enterprises and thereby increasing the activities of foreign firms in the host country (Levine, 1997a). Empirical studies which focused on threshold levels of financial sector development that significantly influence FDI inflows are extremely very scarce. Using cross-country regression analysis, Omran and Bolbol (2003) investigated the minimum threshold levels of banking sector development indicators that significantly influence FDI inflows in Arab countries. Their study used domestic credit from commercial banks to the private sector as a ratio of GDP and commercial banks assets as a ratio of commercial banks and central bank assets as proxies of banking sector development.

The minimum threshold level of commercial banks assets as a ratio of commercial banks and central bank assets that trigger FDI inflows was found to be $47 \%$. The interpretation is that all countries whose minimum threshold level was below $47 \%$ of commercial banks and central bank assets such as Libya, Saudi Arabia, Sudan and Yemen were not in a position to have their banking sector development significantly influence FDI inflows. On the other hand, the banking sector in Lebanon, Tunisia and United Arab Emirates (UAE) were able to attract significant FDI because these countries' banking sector development levels exceeded the threshold level of $47 \%$ of commercial banks and central bank assets (Omran and Bolbol, 2003: 241). Furthermore, the minimum threshold level of domestic credit from commercial banks to the private sector as a ratio of GDP (domestic credit) was found to be $13.8 \%$. Countries such as Jordan, Lebanon and Tunisia whose domestic credit surpassed $13.8 \%$ of GDP were able to significantly attract FDI inflows whilst Sudan, Syria and Yemen failed to attract significant FDI inflow because their domestic credit levels were below the minimum 
threshold target of $13.8 \%$ of GDP. Azman-Saini et al. (2010) studied the role of financial markets on FDI using a threshold regression model in 91 countries with cross country annual data from 1975 to 2005.

Their study used only banking sector development indicators as proxies for financial markets development, namely, credit provided by financial institutions to the private sector to GDP ratio, credit by deposit money banks to the private sector to GDP ratio (bank credit), ratio of commercial bank assets to commercial banks and central bank assets and liquid liabilities (ratio of liquid liabilities of the financial system to GDP) of the banking sector, whilst FDI net inflows (\% of GDP) was used to measure FDI. Their results showed that FDI inflow was significant only when credit provided by financial institutions to the private sector to GDP ratio exceeded a threshold level of $49.7 \%, 43.1 \%$ of GDP for bank credit, $89.1 \%$ of commercial banks and central bank assets and $68.8 \%$ of GDP for liquid liabilities. Using panel regression analysis with data involving 97 countries from Central Asia, Europe, South Asia, East Asia and Pacific, Middle East, North Africa, Sub-Saharan Africa, Latin America and the Caribbean, Dutta and Roy (2011) investigated the minimum threshold level of financial development that allows the host countries to attract significant FDI inflows. FDI net inflow (\% of GDP) and the ratio of private credit by deposit money banks to GDP were used as proxies for FDI and financial development respectively. They found out that the relationship between banking sector development and FDI inflows is a non-linear one and that FDI inflows were positively and significantly influenced by banking sector development only up to a maximum level of private credit by deposit money banks to GDP ratio of $130 \%$. Beyond a threshold of $130 \%$ of GDP, private credit by deposit money banks to GDP ratio had a negative impact on FDI inflows in the host countries (Dutta and Roy, 2011:310).

The finding is consistent with the observation by Hailu (2010) who argued that highly developed financial markets could possibly crowd out FDI. In another study, Hermes and Lensink (2003) investigated the minimum threshold levels of financial development above which developing countries begin to significantly attract FDI inflows during the period between 1970 and 1995. Their study used credit to the private sector as a ratio of GDP, a log of the private sector bank loans and the log of investment share in GDP as proxies of financial development whilst the log of FDI to GDP ratio was used as a measure of FDI. They found that the minimum threshold level of credit to the private sector as a ratio of GDP was $12 \%$. This means that developing countries whose credit to the private sector as a ratio of GDP was below $12 \%$ failed to significantly attract FDI inflows and vice versa for developing countries whose credit to the private sector as a ratio of GDP was above $12 \%$. As earlier observed, prior studies on the relationship between minimum threshold levels of financial sector development and FDI inflows have similar shortcomings. Methodologically, they did not address the endogeneity problem embedded in such FDI-financial sector development relationships. The exclusion of other forms of financial sector development such as the bond and stock markets means that the results are not broad enough to represent the impact of minimum threshold levels of the whole financial sector on FDI inflows. This paper endeavours to address this research gap. In addition to financial sector development there are many other variables that influence FDI inflows. According to Dunning (1980:13), economic growth in the host country is a location advantage of FDI in line with the eclectic paradigm hypothesis.

On the other hand, the market size hypothesis of Jorgenson (1963) argues that FDI is attracted into the host country by the level of GDP. Nnadi and Soobaroyen (2015) observe that higher inflation rate could chase away prospective and already existing foreign investors. Inflation rate increase in host country reduces FDI as it erodes the value of the profits made by foreign firms (Sayek, 2009: 423). The currency areas hypothesis says that weak currencies in the host country attract FDI whilst strong currencies not only deter FDI inflows but promotes FDI outflows (Aliber, 1970). Romer (1986) and Lucas (1988) observe that both domestic and foreign savings lead to long-term economic growth. Trade openness is a political location advantage of FDI that arises from favourable government policies (Denisia, 2010: 108). 0Dunning (1977) noted that human capital development is one of the most important locational advantages that positively affect FDI flows. According to Craigwell (2012), high human capital development helps domestic companies to easily and quickly take advantage of new technology thereby increasing the FDI linked technology spill-overs. Availability of good institutional infrastructure helps the host countries to benefit from technological spillovers of FDI (Wang and Xie, 2009). Craigwell (2012) also observes that in addition to providing a support framework for new technology, sufficient and high quality of infrastructure improves and enhances FDIdomestic firms' linkages. Thus consistent with the literature, domestic savings, trade openness, human capital development and infrastructural development have a positive effect on FDI. Explanatory variables are as 
follows. Stock market capitalization ratio, stock market turnover ratio and stock market value traded ratio are used to capture stock market size, liquidity and efficiency of the stock market.

\section{Research Methodology}

Sources of Data: Data for the study is extracted from the World Development Indicators, International Financial Statistics, International Monetary Fund, African Development Indicators, Global Financial Indicators, United Nations Conference on Trade and Development and United Nations Development Programme various reports. Out of the thirty-one emerging markets listed by IMF (2015), we choose twentyone of them whose data for all variables could be obtained for data consistency purposes (See Appendices 1 and 2 listing countries and variables and acronyms). The study spans from 1994 to 2014 because some of the previous communist countries studied had no stock market prior to 1994. Our dependent variable is net FDI inflows as a ratio of GDP as a measure for FDI because it best measures foreign investors' change in position in the host country (Biglaiser and DeRouen. 2006:59). The domestic credit to private sector ratio and the domestic credit provided by financial sector ratio are used as proxies for banking sector development, whilst outstanding domestic private debt securities and outstanding domestic public debt securities ratios are used as measures of bond sector development. The choice of banking and bond sector development variables is influenced mainly by the availability of data. The control variables include economic growth (GDPPC), exchange rates (EXCHANGE), trade openness (TRADE), infrastructure development (INFR), inflation rate (INFL), human capital development (HCD) and gross savings (GS) consistent with literature (Soumare and Tchana, 2015; Walsh and Yu, 2010; among others).

Estimation Model: We use a modified Kremer et al.'s (2013) dynamic panel threshold regression model. Our study's major focus and theoretical perspective are that there is a minimum threshold level of financial sector development that is conducive to attracting more FDI. Hence, following Kremer et al. (2013) approach, our modified structural equations in respect to different financial development indicators and explanatory variables are as follows:

$$
\begin{aligned}
& F D I_{\mathrm{it}}=\mu_{\mathrm{i}}+\beta_{1} F D I_{\mathrm{it}-1}+\beta_{2} \operatorname{Stock}_{\mathrm{it}} \mathrm{I}\left(\operatorname{Stock}_{\mathrm{it}} \geq \gamma\right)+\delta_{\mathrm{i}} \mathrm{I}\left(\operatorname{Stock}_{\mathrm{it}} \geq \gamma\right)+\beta_{3} \operatorname{Stock}_{\mathrm{it}} \mathrm{I}\left(\operatorname{Stock}_{\mathrm{it}}<\gamma\right)+\varphi z_{\mathrm{it}}+\varepsilon i t \\
& \left.F D I_{\mathrm{it}}=\mu_{\mathrm{i}}+\beta_{1} F D I_{\mathrm{it}-1}+\beta_{2} \operatorname{Bank}_{\mathrm{it}} \mathrm{I}\left(\operatorname{Bank}_{\mathrm{it}} \geq \gamma\right)+\delta_{\mathrm{i}} \mathrm{I} \operatorname{Bank}_{\mathrm{it}} \geq \gamma\right)+\beta_{3} \operatorname{Bank}_{\mathrm{it}} \mathrm{I}_{\left(\operatorname{Bank}_{\mathrm{it}}<\gamma\right)+\varphi Z_{\mathrm{it}}+\varepsilon i t}
\end{aligned}
$$

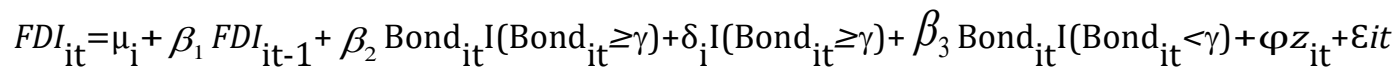
$F D I_{\text {it }}$ is the ratio of net FDI inflow over GDP for country i at time t, $\varphi z_{\text {it }}$ stands for control variables, $\mu_{i}$ is the specific country fixed effect; $\gamma$ represents the threshold level, $\beta_{1}, \beta_{2}$ and $\beta_{3}$ are the slope coefficients. $\delta_{i}$ stands for the regime intercepts which address the bias caused by the correlation between an explanatory

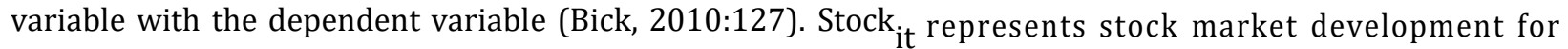
country $\mathrm{i}$ at time $\mathrm{t}$. Bank $\mathrm{it}_{\mathrm{it}}$ stands for banking sector development for country $\mathrm{i}$ at time $\mathrm{t}$, whilst Bond $\mathrm{it}_{\mathrm{it}}$ represents bond market development for country i at time t. I (.) is the indicator function showing the regime defined by the threshold variable (Stock, Bank or Bond). The error term (Eit) is independently and identically distributed with constant variance and mean of zero. $z_{i t}$ represents a vector of the independent set of explanatory variables which include both endogenous and exogenous variables. $z_{i t}$ is further partitioned into two, namely $z 1_{i t}$ which contains exogenous variables which are not correlated with the error term (Eit) and $\mathrm{z} 2_{\text {it }}$ which include the endogenous variables which are correlated with Eit. For our study, $\mathrm{z}_{\text {it }}$ constitutes all the control variables (GDPPC, INFL, EXCHANGE, GS, TRADE, HCD and INFR) and the threshold variable (Stock, Bank or Bond) $\mathrm{z}_{\mathrm{it}}$ is the lag of the dependent variable $\left(F D I_{\mathrm{it}-1}\right)$ which is the only endogenous variable. We employ GMM estimators to address the endogeneity problem. 
Whilst using all the available lags of the dependent variable as instruments $(p=t)$ increases the level of efficiency in the model, our study uses only one lag of the dependent variable as an instrument $(p=1)$ to avoid an over-fit of instrumental variables that might produce coefficient estimates which are biased (Roodman, 2009). Following Kremer et al. (2013:864), eliminating the individual country-specific fixed effects $\left(\mu_{\mathrm{i}}\right)$ is the

first step in the estimation of the threshold levels. Hansen (1999) uses the standard within transformation approach to eliminate the individual country-specific fixed effects whose weaknesses are: (1) it leads to inaccurate estimates because the lagged dependent variable remains correlated with the error term; and (2) the first differencing applied to remove the country-specific fixed effects results in negative serial correlation in the error term. Our study uses the forward orthogonal deviations transformation which subtracts the average of each variable's future observations, thereby avoiding the serial correlation of the transformed error terms. The approach consequently enables a cross-sectional model by Caner and Hansen (2004) to be applied to a dynamic panel threshold model set up. It also guarantees that the explanatory variables are uncorrelated with the error term, thereby helping in addressing the endogeneity problem (Matemilola et al., 2016:441).

There are six steps involved in the estimation of threshold levels. The first stage involves the elimination of individual country-specific fixed effects $\left(\mu_{\mathrm{i}}\right)$ using the forward orthogonal deviations transformation approach, whose superiority has been explained in the preceding paragraph. Secondly, a reduced form regression equation for the endogenous variable $\left(\mathrm{z}_{\mathrm{it}}\right)$ as a function of the instruments $\left(\mathrm{x}_{\mathrm{it}}\right)$ is estimated, following Caner and Hansen (2004). Thirdly, the endogenous variables $\left(\mathrm{z}_{\mathrm{it}}\right)$ are replaced in the structural equations by their predicted endogenous values $\left(\hat{z} 2_{i t}\right)$, consistent with the Kremer et al. (2013:865) approach. Fourthly, the structural equations are then estimated using ordinary least squares for a fixed threshold $\gamma$ where the endogenous variables $\left(\mathrm{z}{ }_{\mathrm{it}} \mathrm{S}\right)$ are then replaced by their predicted values from the third step of the estimation process. The sum of squared residuals represented by $\mathrm{S}(\gamma)$ results from the fourth stage. The fourth stage is repeated for a strict subset of the threshold variable (Stock, Bank or Bond). The fifth stage involves the estimator of the threshold value $\mathbf{S}(\gamma)$ denoted by $(\hat{\gamma})$ being chosen as the one with the smallest sum of the squared residuals $S(\gamma)$. Once the threshold value $\gamma$ has been estimated, the sixth and final stage involves the precise slope coefficients being estimated using the generalised method of moment (GMM) approach.

\section{Results and Discussion}

Descriptive Statistics: Table 1 below shows mean values of variables by country, where TURN stands for stock market turnover ratio, VTRD represents stock market value traded ratio, MCAP is stock market capitalisation, DCRED stands for domestic credit to private sector ratio, DCFS is domestic credit provided by financial sector ratio, DPRDS stands for outstanding domestic private debt securities and DPBDS represents outstanding domestic public debt securities ratio.

Table 1: Mean of Key variables by Country (1994 to 2014)

\begin{tabular}{|c|c|c|c|c|c|c|c|c|}
\hline & FDI & TURN & VTRD & MCAP & DCRED & DCFS & DPRDS & DPBDS \\
\hline Argentina & 2.34 & 34.86 & 5.43 & 15.40 & 15.48 & 31.94 & 4.43 & 13.43 \\
\hline Brazil & 2.72 & 55.78 & 23.93 & 44.03 & 42.87 & 79.68 & 16.87 & 44.85 \\
\hline China & 3.85 & 160.86 & 60.71 & 39.42 & 113.19 & 128.30 & 16.68 & 11.05 \\
\hline Colombia & 3.33 & 11.23 & 4.50 & 32.33 & 35.43 & 49.55 & 0.47 & 18.07 \\
\hline Czech Republic & 4.76 & 48.06 & 10.32 & 19.00 & 45.51 & 56.39 & 7.93 & 20.55 \\
\hline Greece & 0.74 & 54.12 & 24.73 & 44.97 & 74.46 & 105.48 & 11.81 & 58.86 \\
\hline Hong Kong & 20.63 & 54.01 & 342.78 & 628.51 & 163.10 & 157.91 & 15.30 & 16.10 \\
\hline Indonesia & 1.62 & 37.66 & 11.02 & 32.29 & 33.36 & 47.85 & 3.65 & 11.64 \\
\hline India & 1.29 & 102.44 & 42.71 & 56.20 & 36.80 & 59.03 & 1.94 & 10.35 \\
\hline Mexico & 2.61 & 29.46 & 8.33 & 28.98 & 21.21 & 37.24 & 10.92 & 15.35 \\
\hline Malaysia & 3.65 & 29.02 & 41.63 & 154.99 & 121.35 & 132.99 & 45.66 & 35.71 \\
\hline Peru & 4.32 & 14.59 & 3.83 & 34.82 & 24.13 & 19.93 & 10.84 & 3.11 \\
\hline
\end{tabular}




\begin{tabular}{lllllllll}
\hline Philippines & 1.56 & 22.77 & 12.88 & 57.38 & 35.39 & 54.77 & 1.20 & 30.93 \\
Poland & 3.32 & 47.69 & 8.99 & 23.15 & 31.85 & 46.48 & 0.95 & 19.24 \\
Portugal & 3.35 & 59.41 & 22.06 & 34.95 & 135.61 & 143.14 & 36.43 & 37.59 \\
Republic of Korea & 0.89 & 179.16 & 100.92 & 60.94 & 104.66 & 114.80 & 54.89 & 22.65 \\
Russia & 2.05 & 37.92 & 22.22 & 40.34 & 28.23 & 31.89 & 3.08 & 4.42 \\
Thailand & 3.01 & 72.36 & 43.90 & 61.39 & 119.93 & 137.49 & 22.88 & 16.78 \\
Turkey & 1.32 & 148.30 & 37.49 & 27.07 & 31.04 & 50.42 & 0.38 & 24.19 \\
Singapore & 16.00 & 54.39 & 101.59 & 194.42 & 100.87 & 79.13 & 14.23 & 30.19 \\
South Africa & 1.54 & 23.93 & 47.67 & 197.16 & 133.48 & 164.40 & 15.71 & 34.33 \\
Overall Mean & 4.04 & 60.86 & 46.55 & 87.04 & 68.95 & 82.32 & 14.11 & 22.83 \\
\hline
\end{tabular}

Overall, the mean values show an uneven pattern of FDI inflows and financial sector development among emerging markets. The Czech Republic, Hong Kong, Peru and Singapore attract high FDI inflows than their peers while Greece and the Republic of Korea attract the least. With regard to financial sector development, there is a mixed pattern depending on which indicator is being measured. However, in terms of the size of stock markets, Hong Kong, Malaysia, Singapore and South Africa fare much better than their peers.

Econometric Results: Table 2 shows threshold levels and regression results of the nexus between financial sector development and FDI. The lag of FDI positively and significantly influenced FDI inflows in emerging markets, consistent with Walsh and Yu (2010) who observed that existing FDI stock influences future FDI through allowing new foreign investors to easily enjoy positive spill-over benefits generated by the already established foreign investors in the host country. The threshold levels in Table 2 are significant. A positive but insignificant impact of TURN on FDI inflows at levels above or equal to the threshold of $41.27 \%$ of MCAP is observed. TURN levels that are less than a threshold value more positively and significantly influenced FDI inflows. These results deviate from the conventional literature on the relationship between financial sector development and FDI inflows. However, they resonate with Havranek and Irsova (2011) who reported that foreign investors can bring along significant FDI inflows despite the prevalence of lower financial sector development (FSD) in the host country as long as they have a small technological edge over local firms and are open to trade with other countries. The size of the coefficients shows that VTRD at levels above or equal to the threshold of $53.55 \%$ of GDP more positively and significantly influenced FDI inflows in comparison to the impact of VTRD levels that are less than a threshold on FDI inflows.

The results are consistent with a study by Levine (1997b) which observed that FDI projects are only viable under conditions of high stock market liquidity as this enables the less costly and easy raising of additional capital by foreign investors in the host country. Whilst MCAP at levels less than the threshold value of $121.53 \%$ of GDP had a significant positive impact on FDI inflows. Levels of MCAP greater or equal the threshold level had a more positive and more significant influence on FDI inflows. The results support the allocative channel theoretical rationale which stipulates that higher developed financial markets are better able to increase productivity of foreign capital through being better able to allocate financial resources to projects with high rate of return (Claessens and Laeven, 2003). Although DCRED levels less than the threshold level of $114.43 \%$ of GDP had a positive and significant influence on FDI inflows, the levels of DCRED equal to or above a threshold level had a more positive and more significant impact on FDI inflows. The results support the economic efficiency rationale which according to Bartels et al. (2009) says that developed financial markets are better able to provide timely, efficient and cost-cutting information to potential foreign investors thereby contributing to a decline in the level of asymmetric information that normally curtails international capital mobility.

Table 2: Dynamic Panel Threshold Regression Model Results

\begin{tabular}{|c|c|c|c|c|c|c|}
\hline \multirow{3}{*}{ Thresh. Est. } & \multicolumn{3}{|c|}{$\begin{array}{c}\text { Model 1: FDI= f(TURN, INITIAL, } \\
\text { CONTROLS) }\end{array}$} & \multicolumn{3}{|c|}{$\begin{array}{c}\text { Model 2: FDI= f(VTRD, INITIAL, } \\
\text { CONTROLS ) }\end{array}$} \\
\hline & \multirow{2}{*}{$\begin{array}{l}41.27 \% . \\
\text { Coefficient }\end{array}$} & \multicolumn{2}{|c|}{ C.I. [7.77\%-126.47\%] } & \multirow{2}{*}{$\begin{array}{l}53.55 \% . \\
\text { Coefficient }\end{array}$} & \multicolumn{2}{|c|}{ C.I. [7.77\%-90.02\%] } \\
\hline & & Std. error & T Statistic & & Std. error & T Statistic \\
\hline$\beta_{1}$-Initial & $0.1823^{*}$ & 0.0985 & 1.8508 & $0.2685^{* * *}$ & 0.0867 & 3.0969 \\
\hline$\beta_{2}$ & $0.2136^{* *}$ & 0.1021 & 2.0921 & $0.6502^{* * *}$ & 0.1023 & 6.3558 \\
\hline
\end{tabular}




\begin{tabular}{|c|c|c|c|c|c|c|}
\hline$\beta_{3}$ & $0.2058^{*}$ & 0.1154 & 1.7834 & $0.1827^{* * *}$ & 0.0522 & 3.5000 \\
\hline$\delta_{\mathrm{i}}$ & $1.2152^{*}$ & 0.6419 & 1.8931 & $1.3493^{* * *}$ & 0.4531 & 2.9779 \\
\hline GDPPC & $0.2566^{* *}$ & 0.1155 & 2.2216 & 0.1775 & 0.1127 & 1.5750 \\
\hline INFL & -0.0092 & 0.0430 & -0.2140 & 0.0071 & 0.0431 & 0.1647 \\
\hline EXCHANGE & $0.1722^{* *}$ & 0.0823 & 2.0923 & $0.1603^{* *}$ & 0.0790 & 2.0291 \\
\hline GS & 0.0898 & 0.2826 & 0.3178 & 0.0467 & 0.2909 & 0.1605 \\
\hline TRADE & 0.3600 & 0.2335 & 1.5418 & 0.1278 & 0.2219 & 0.5759 \\
\hline HCD & 0.1142 & 0.5613 & 0.2035 & -0.2234 & 0.5622 & -0.3974 \\
\hline \multirow[t]{2}{*}{ INFR } & -0.2996 & 0.2367 & -1.2657 & -0.3409 & 0.2345 & -1.4537 \\
\hline & $\begin{array}{lr}\text { Model } 3 \\
\text { CONTROLS) }\end{array}$ & \multicolumn{2}{|c|}{ f(MCAP, INITIAL, } & $\begin{array}{l}\text { Model } \\
\text { CONTROLS }\end{array}$ & $\begin{array}{l}4: F D I= \\
\text { S) }\end{array}$ & $\mathrm{f}(\mathrm{DCRED}$, \\
\hline \multirow[t]{2}{*}{ Thresh. Est. } & $121.53 \%$ & \multicolumn{2}{|c|}{ C.I.[68.03\%-160.77\%] } & $114.43 \%$ & \multicolumn{2}{|c|}{ C.I. $[29.96 \%-138.38 \%]$} \\
\hline & Coefficient & Std. error & T Statistic & Coefficient & Std. error & T Statistic \\
\hline$\beta_{1}$-Initial & $0.4063^{* * *}$ & 0.0820 & 4.9549 & $0.3182^{* * *}$ & 0.0851 & 3.7391 \\
\hline$\beta_{2}$ & $1.0578^{* * *}$ & 0.1611 & 6.5661 & $1.9994^{* * *}$ & 0.5467 & 3.6572 \\
\hline$\beta_{3}$ & $0.1459 * *$ & 0.0711 & 2.0520 & $0.2761^{* *}$ & 0.1395 & 1.9792 \\
\hline$\delta_{\mathrm{i}}$ & $1.3482^{* * *}$ & 0.4394 & 3.0683 & $1.0934^{* *}$ & 0.4391 & 2.4901 \\
\hline GDPPC & 0.0758 & 0.1085 & 0.6986 & 0.0608 & 0.1409 & 0.4315 \\
\hline INFL & -0.0049 & 0.0450 & -0.1089 & -0.0237 & 0.0442 & -0.5362 \\
\hline EXCHANGE & 0.0953 & 0.0779 & 1.2234 & 0.1065 & 0.0787 & 1.3532 \\
\hline GS & 0.1340 & 0.3008 & 0.4455 & 0.3293 & 0.2849 & 1.1558 \\
\hline TRADE & -0.1095 & 0.2346 & -0.4668 & 0.0200 & 0.2221 & 0.0901 \\
\hline HCD & -0.1269 & 0.5942 & -0.2136 & 0.2423 & 0.5724 & 0.4233 \\
\hline INFR & -0.1031 & 0.2126 & -0.4849 & -0.0894 & 0.2477 & -0.3609 \\
\hline
\end{tabular}

Table 2 continued

Model 5:FDI= f(DCFS, INITIAL, CONTROLS)

Coefficient Std. error T Statistic

Model $\quad 6: F D I=\quad f(D P R D S, \quad$ INITIAL, CONTROLS)

$0.22 \%$.

C.I. $[0.21 \%-35.87 \%]$

$\beta_{1}$-Initial

$0.4285^{* * *}$

0.0811

5.2836

Coefficient

Std. error

T Statistic

$\beta_{2}$

0.8579

4.5606

$\beta_{3}$

$3.9125^{* * *}$

$0.2613^{* * *}$

0.0855

3.0561

0.2261

0.8734

0.2589

$\delta_{\mathrm{i}}$

$-0.0041$

0.1494

$-0.0274$

0.0115

0.0723

0.1591

GDPPC

1.7358*

1.0035

1.7297

0.1249

0.8863

INFL

$-0.0348$

0.0442

$-0.7873$

EXCHANGE

0.0762

0.0821

0.9281

0.3153

1.2077

0.2300

0.0243

TRADE

0.0056

0.5792

0.4625

INFR

0.2679

0.2358

$-0.4551$

0.0213

0.1256

0.1696

$0.3156^{* * *}$

0.1164

2.7113

$-0.0253$

0.0426

$-0.5939$

0.1287

0.0800

1.6088

0.1642

0.6274

0.2864

1.2678

0.0843

0.2259

0.1486

Model 7:FDI $=\mathrm{f}($ DPBDS, INITIAL, CONTROLS)

Thresh. Est.

$41.26 \%$.

C.I.[2.61\%-41.26\%]

Coefficient Std. error T Statistic

$\beta_{1}$-Initial

$0.3300^{* * *}$

0.0820

4.0244

$\beta_{2}$

$-1.7457$

1.2461

$-1.4009$

$\beta_{3}$

0.0014

0.0503

0.0278

$\delta_{\mathrm{i}}$

$-1.2352$

1.2189

$-1.0134$ 


\begin{tabular}{llll} 
GDPPC & $0.2613^{* *}$ & 0.1137 & 2.2982 \\
INFL & -0.0277 & 0.0424 & -0.6533 \\
EXCHANGE & $0.1613^{* *}$ & 0.0768 & 2.1003 \\
GS & 0.3484 & 0.2709 & 1.2861 \\
TRADE & 0.2707 & 0.2403 & 1.1265 \\
HCD & -0.2891 & 0.5650 & -0.5117 \\
INFR & -0.5189 & 0.2442 & -2.1249 \\
\hline
\end{tabular}

$* / * * / * *$ indicate $10 \% / 5 \% / 1 \%$ respectively

DCFS at levels below a threshold of $144.06 \%$ of GDP negatively influenced FDI inflow whereas DCFS equal to or greater than a threshold level had a strong positive and significant impact on FDI inflows. The findings agree with Agbloyor et al. (2014) who showed that less developed financial markets are unable to efficiently allocate foreign capital towards the productive economic sectors thereby exposing the host country to financial and exchange rate crises which lead not only to the outflow of foreign capital but also stifle economic growth. DPRDS at levels below the threshold of $0.22 \%$ of GDP has a weak positive but non-significant impact on FDI inflows whilst DPRDS at levels that are equal or above a threshold has a stronger positive but insignificant impact on FDI inflows. Levels of DPBDS below a threshold of $41.26 \%$ of GDP positively influenced FDI inflows whilst DPBDS at levels above the threshold negatively influenced FDI inflows, a finding which contradicts most conventional literature on the subject matter. The theoretical explanation could be that foreign investors might prefer portfolio investment in a more developed and functioning financial system which could lead to portfolio investments crowding out FDI (Hailu, 2010:109).

The results resemble those of Tan \& Ismail (2015) who observed that high government debt crowds out investment (foreign and domestic) and consequently lowers economic growth. None of the threshold slope coefficients of bond sector development is significant. This could be driven by the low level of development of the bond markets which cannot attract, absorb and efficiently allocate foreign capital. As control variables, GDPPC, EXCHANGE, TRADE and GS positively influenced FDI whilst INFL negatively affected FDI in the majority of cases in line with theoretical expectations. INFR (proxied by electric power consumption) negatively affected FDI in contrast with the eclectic paradigm hypothesis but consistent with the observation by Lopez-Carlos and Schwab (2007). The latter argued that countries with high energy consumption have adequate foreign currency reserves to sponsor their own homegrown economic growth initiatives without help from MNEs. HCD positively influenced FDI in model 1, 4, 5 and 6, in support of Mastromarco and Ghosh (2009) who argued that HCD guaranteed the efficiency of FDI in developing countries. It negatively influenced FDI in model 2, 3 and 7, consistent with Kang and Lee (2007) who noted that high cost of labour which is associated with high levels of HCD negatively affects FDI through increasing the cost of doing business on the part of foreign investors.

General Discussion: Omran and Bolbol (2003) observed that countries whose (1) domestic credit and commercial banks assets as a ratio of commercial banks and central bank assets and (2) domestic credit from commercial banks to the private sector as a ratio of GDP were below a threshold of $47 \%$ and $3.8 \%$ respectively failed to enjoy significant FDI. Furthermore, Hermes and Lensink (2003) reported that developing countries whose credit to the private sector (\% of GDP) was below a threshold of $12 \%$ failed to attract significant FDI inflows. Azman-Saini et al. (2010) show that significant FDI inflow only was realised in the host countries when private sector credit ratio exceeded a threshold level of $49.7 \%$ of GDP, $43.1 \%$ of GDP for bank credit, $89.1 \%$ of commercial banks and central bank assets for domestic credit and commercial bank assets ratio and $68.8 \%$ of GDP for liquid liabilities ratio. Our results differ from the above findings in two ways. Firstly, our minimum threshold levels for banking sector development variables are much higher, $114.43 \%$ of GDP for DCRED and $144.06 \%$ of GDP for DCFS. Secondly, our study shows that countries whose levels of DCRED were below the threshold positively and significantly influenced FDI inflows whilst emerging countries whose DCRED were equal to and above the threshold more positively and more significantly received FDI inflows. In contrast, the above similar empirical studies noted that countries characterised by banking sector development below the threshold level did not benefit from FDI at all.

Dutta and Roy (2011) reported that banking sector development positively influenced FDI inflows only up to maximum level of private credit by deposit money banks to GDP ratio of $130 \%$, beyond which FDI outflow is 
triggered. On the contrary, our results show that a country whose DCRED is above a threshold level of $114.43 \%$ of GDP managed to significantly attract FDI inflows. Our study expanded the discussion by also focusing on threshold levels of stock market and bond sector development variables required to influence FDI inflows in emerging markets unlike the prior similar empirical studies which neglected both stock and bond markets. The results of our study are more robust than those of the prior similar studies because we eliminated individual country specific effects using a superior approach known as forward orthogonal deviations transformation. Moreover, we investigated financial sector development minimum threshold levels on FDI inflows using a dynamic panel threshold regression model that addressed endogeneity problems.

\section{Concluding Remarks}

Our study concludes that higher banking sector and stock market development is important in attracting significant FDI inflows in the emerging markets. Higher levels of private bond sector development equal to or above the threshold have a positive but insignificant impact on FDI inflows, whilst lower private bond sector development below the threshold has a weaker positive and non-significant influence on FDI inflows in line with theoretical predictions. Higher levels of public bond sector development equal to or above the threshold negatively influenced FDI inflows in emerging markets, whilst public bond sector development levels below the threshold positively but non-significantly influenced FDI inflows in contrast with theoretical predictions. Emerging markets are therefore urged to implement policies that entrench the development of the banking sector, stock market and private bond market in order to sustain the inflow of significant FDI. The study also encourages the emerging markets to implement a policy that ensures that public bond market development is kept at reasonably low levels in order to avoid crowding out FDI. We assumed that there is only one minimum threshold level of financial sector development that has to be reached before emerging markets significantly influence FDI inflows, which might not be realistic for such non-linear relationships. We therefore recommend that future studies must investigate the existence of multiple thresholds of financial sector development that influence FDI inflows.

Acknowledgement: This research paper is a product of my unpublished $\mathrm{PhD}$ thesis entitled: The impact of financial sector development on foreign direct investment in emerging markets.

\section{References}

Agbloyor, E. K., Abor, J. Y., Adjasi, C. K. D. \& Yawson, A. (2014). Private capital flows and economic growth in Africa: The role of domestic financial markets. Journal of International Financial Markets, Institutions \& Money, 30, 137-152.

Aliber, R. Z. (1970). A theory of direct foreign investment. The International Corporation, Cambridge, 17-34.

Asong, S. A. (2014). Linkages between investment flows and financial development. African Journal of Economic and Management Studies, 5(3), 269-299.

Azman-Saini, W. N. W., Law, S. H. \& Ahmad, A. H. (2010). FDI and economic growth: New evidence on the role of financial markets. Economic Letters, 107(2), 211-213.

Balasubramanyam, V. N., Salisu, M. \& Sapsford, D. (1996). Foreign direct investment and growth in EP and IS countries. The Economic Journal, 106(1), 92-105.

Bartels, F. L., Alladina, S. N. \& Lederer, S. (2009). Foreign direct investment in Sub-Saharan Africa: Motivating factors and policy issues. Journal of African Business, 10(2), 141-162.

Bick, A. (2010). Threshold effects of inflation on economic growth in developing countries. Economic Letters, 108(2), 126-129.

Biglaiser, G. \& DeRouen, K. (2006). Economic reforms and inflows of foreign direct investment in Latin America. Latin American Research Review, 41(1), 51-75.

Caner, M. \& Hansen, B. E. (2004). Instrumental variable estimation of a threshold model. Economic Theory, 20 (5), 813-843.

Choong, C. K. (2012). Does domestic financial development enhance the linkages between foreign direct investment and economic growth? Empirical Economics, 42(3), 819-834.

Claessens, S. \& Laeven, L. (2003). Financial development, property rights and growth. The Journal of Finance, 8(6), 2401-2435. 
Craigwell, M. F. A. W. R. (2012). Economic growth, foreign direct investment and corruption in developed and developing countries. Journal of Economic Studies, 39(6), 639-652.

Denisia, V. (2010). Foreign direct investment theories: An overview of the main FDI theories. European Journal of Interdisciplinary Studies, 2(2), 104-110.

Dunning, J. H. (1977). Trade location of economic activity and the MNE: A search of an eclectic approach, in B. Ohlin, P.O. Hesselborn and P.J. Wijkman, The international allocation of economic activity. Macmillan, London.

Dunning, J. H. (1980). Toward an eclectic theory of international production: Some empirical tests. Journal of International Business Studies, 11(1), 9-31.

Dutta, N. \& Roy, S. (2011). Foreign direct investment, financial development and political risks. The Journal of Developing Areas, 44(2), 303-327.

Ezeoha, A. E. \& Cattaneo, N. (2012). FDI flows to Sub-Saharan Africa: The impact of finance, institution and natural resource endowment. Comparative Economic Studies, 54(3), 597-632.

Hailu, Z. A. (2010). Demand side factors affecting the inflow of foreign direct investment to African countries: Does capital market matter? International Journal of Business and Management, 5(5), 103-112.

Hansen, B. E. (1999). Threshold effects in non-dynamic panels: Estimation, testing and inference. Journal of Econometrics, 93(2), 345-368.

Havranek, T. \& Irsova, Z. (2011). Estimating vertical spill overs from FDI: Why results vary and what the true effect is. Journal of International Economics, 85(2), 234-244.

Hermes, N. \& Lensink, R. (2003). Foreign direct investment, financial development and economic growth. Journal of Development Studies, 40(1), 142-163.

Huang, H. \& Xu, C. (1999). Institutions, innovations and growth. American Economic Review, 89(2), 438-443.

IMF. (2015). World Economic Outlook: Adjusting to Lower Commodity Prices. Washington (October).

Jorgenson, D. W. (1963). Capital theory and investment behaviour. The American Economic Review, 53(2), 247-259.

Kang, S. J. \& Lee, H. S. (2007). The determinants of location choice of South Korean FDI in China. Japan and the World Economy, 19(4), 441-460.

Kaur, M., Yadav, S. S. \& Gautam, V. (2013). Financial system development and foreign direct investment: A panel study for BRICS countries. Global Business Review, 14(4), 729-742.

Kremer, S., Bick, A. \& Nautz, D. (2013). Inflation and growth: New evidence from a dynamic pane Threshold analysis. Empirical Economics, 44(2), 861-878.

Levine, R. (1997a). Financial development and economic growth: Views and Agenda. Journal of Economic Literature, 35(2), 688-726.

Levine, R. (1997b). Stock markets, economic development and capital control liberalisation. Perspectives, $3(5), 1-7$.

Lopez-Carlos, A. \& Schwab, K. (2007). The Arab World Competitiveness Report 2007, World Economic Forum, Palgrave MacMillan, London.

Lucas, R. (1988). On the mechanics of economic development. Journal of Monetary Economics, 22(1), 3-42.

Mastromarco, C. \& Ghosh, S. (2009). Foreign capital, human capital and efficiency: A stochastic frontier analysis for developing countries, World Development, 37(2), 489-502.

Matemilola, B. T., Bany-Ariffin, A. N., Azman-Saini, W. N. W. \& Nassir, A. M. (2016). Non-linearity in debt and return relationship: Evidence from dynamic panel threshold method, Journal of Applied Sciences, 16(9), 438-444.

Nnandi, M. \& Soobaroyen, T. (2015). International financial reporting standards and foreign direct investment: The case of Africa. Advances in accounting, 31(2), 228-238.

Omran, M. \& Bolbol, A. (2003). Foreign direct investment, financial development and economic growth: Evidence from the Arab countries. Review of Middle East Economics and Finance, 1(3), 231-249.

Romer, P. (1986). Increasing returns and long run economic growth. Journal of Political Economy, 94(5), 1002-1037.

Roodman, D. A. (2009). Note on the theme of too many instruments. Oxford Bulletin of Economics and Statistics, 71 (1), 135-158.

Sayek, S. (2009). Foreign direct investment inflation. Southern Economic Journal, 76(2), 419-443.

Sghaier, I. M. \& Abida, Z. (2013). Foreign direct investment, financial development and economic growth: Empirical evidence from North African countries. Journal International and Global Economic Studies, 6(1), 1-13. 
Soumare, I. \& Tchana, F. T. (2015). Causality between FDI and financial market development: Evidence from emerging markets. The World Bank Economic Review, 29 (Supplement 1), 1-12.

Tan, A. \& Ismail, N. W. (2015). Foreign direct investment, sovereign debt and growth: Evidence for the Euro Area, American Journal of Trade and Policy, 2 (1), 51-58.

UNCTAD. (2012). WorldInvestmentReport2012. New York: United Nations

Vita, G. \& Kyaw, K. (2009). Growth effects of FDI and portfolio investment flows to developing countries: A disaggregated analysis by income levels, Applied economics letters, 16(3), 277-283.

Walsh, J. P. \& Yu, J. (2010). Determinants of FDI: A sectoral and institutional approach, 187, 1-27.

Wang, H. \& Xie, X. (2009). On effects of foreign direct investment on economic growth. International business research journal, 2(4), 100-108.

\section{List of Appendices}

\begin{tabular}{llll}
\multicolumn{3}{l}{ Appendix A: List of Emerging Markets Studied } & \\
\hline \multicolumn{2}{l}{ Table 3: List of emerging markets studied per region } & Africa \\
\hline Europe & Latin America & Asia & South Africa \\
Czech Republic & Argentina & China & \\
Greece & Brazil & Hong Kong & \\
Poland & Colombia & Indonesia & \\
Portugal & Mexico & India & \\
Russia & Peru & Malaysia & \\
Turkey & & Philippines & \\
& & Republic of Korea & \\
& & Thailand & \\
\hline
\end{tabular}

Source: Author's compilation based on IMF (2015) Indices

\begin{tabular}{|c|c|c|}
\hline \multicolumn{3}{|c|}{ Table 4: Variables, proxies and acronyms } \\
\hline Variable & Proxy & Acronym of the proxy \\
\hline Banking & Domestic credit to private sector by banks (\% of GDP) & DCRED \\
\hline development & Domestic credit provided by financial sector (\% of GDP) & DCFS \\
\hline Stock market & Stock market turnover (\%) & TURN \\
\hline development & Stock market traded value ( $\%$ of GDP) & VTRD \\
\hline & Stock market capitalization (\% of GDP) & MCAP \\
\hline market & Outstanding domestic private debt securities (\% of GDP) & DPRDS \\
\hline development & Outstanding domestic public debt securities (\% of GDP) & DPBDS \\
\hline $\begin{array}{l}\text { Foreign } \\
\text { investment }\end{array}$ & Net Foreign Direct Investment (\% of GDP) & FDI \\
\hline Economic growth & Gross domestic product per capita & GDPPC \\
\hline Inflation & Inflation consumer prices (annual \%) & INFL \\
\hline Foreign exchange rate & Local currency/United States Dollar & EXCHANGE \\
\hline Gross savings & Gross domestic savings (\% of GDP) & GS \\
\hline Trade openness & Total imports + exports (\% of GDP) & TRADE \\
\hline $\begin{array}{ll}\text { Human } & \text { capital } \\
\text { development }\end{array}$ & Human capital development index & HCD \\
\hline $\begin{array}{l}\text { Infrastructural } \\
\text { development }\end{array}$ & Electric power consumption (kWh per capita) & INFR \\
\hline
\end{tabular}

Source: Author's compilation 